\title{
Measuring Market Structures in the Dairy Market in the Czech Republic
}

\author{
Ekaterina Mikhalkina $^{1}$, Mansoor Maitah ${ }^{1}$ \& Karel Šrédl ${ }^{1}$ \\ ${ }^{1}$ Faculty of Economics and Management, Czech University of Life Sciences, Prague, Czech Republic \\ Correspondence: Mansoor Maitah, Faculty of Economics and Management, Czech University of Life Sciences, \\ Kamýcká 129, 165 00, Prague, Czech Republic. Tel: 42-022-438-2139. E-mail: maitah@pef.czu.cz
}

Received: May 9, 2015 Accepted: May 21, 2015 Online Published: July 6, 2015

doi:10.5539/ass.v11n21p306

URL: http://dx.doi.org/10.5539/ass.v11n21p306

\begin{abstract}
The aim of the paper is to illustrate the existing measures of measuring market structures and demonstrate the use of these measures for the selected industry. For the analysis was taken the dairy market in the Czech Republic in the year 2012. This market includes four main stages: milk production; processing and pasteurization of milk; wholesale and retail of milk. The outcome of the analysis determines concentration ratios and types of competition at each stage of the dairy market. Calculations are demonstrated under the Czech antitrust law which operates under the Act no. 143/2001 Coll., On Protection of Competition. Calculations presented in the article can be used by antitrust authorities for evaluating types of competition and concentration ratios within a market. Among the main priorities of the calculations performed in the paper is its simplicity that does not require a large collection of data and complex mathematical calculations.
\end{abstract}

Keywords: concentration ratio, Herfindahl-Hirshman index, Lerner index, market power, market share, oligopoly

\section{Introduction}

The article describes indicators for measuring market structures that internationally used by competition authorities in the fight against market failures, mainly in the fight against uncompetitive markets. Imperfect competition may harm consumers, discriminate one producer over another and thus is ineffective and undesirable in each market. Indicators of market concentrations are used by antitrust authorities in identifying the possibility of breaking antitrust laws. Indicators of market concentrations are easily measurable what helps in prediction of possible abuse of a dominant position in a market. Thus, these indicators are an important part of the analysis and examination of the market. Markets with high concentration ratios are suggested to be imperfect. Markets with low concentration ratios are suggested to be perfectly competitive and hence, the intervention of antitrust authorities is futile. Markets with high concentration ratios do not necessary mean that these markets are inefficient, but abuse of a dominant position is easier exactly at these types of markets. If antitrust authorities find a high market concentration, further investigation and exploration should be started. For example, antitrust authorities should identificate deeper each company in the market; check its financial documentation, suppliers and customers, evaluate firm's market prices and quantites produced using further methods of financial and strategic analysis.

\section{Method}

Market power identifies the "degree of a control that has a single company or group of companies over the decision about output and prices in a given market" (Samuelson, 2013). Among the most commonly used indicators for measuring market power are concentration ratios. Because an oligopoly consists of a small amount of larger firms, which produce a larger portion of output in the sector, production and thus revenues are highly concentrated. For example, studies for the oligopolistic competition have prooved that in the United States of America there is more than $75 \%$ of the total market is divided among the 10 strongest firms. In some oligopolistic structures just two or four strongest firms hold $90 \%$ of the total market (U.S. Census Bureau, 2009).

The aim of the paper is to illustrate the existing measures of market structures and illustrate the use of these indicators for the selected sectors. For the analysis was taken the dairy market in the Czech Republic for the year 
2012. This market includes four main stages: milk production, processing and pasteurization of dairy products, wholesale and retail. The outcome of the analysis will estimate a type of competition and evaluate market concentration ratios at each level of the market. Calculations were conducted in the Czech Republic under the Czech antitrust law. Examples of measuring market concentrations presented in the paper can be also used as an outline for the evaluation of a type of competition for antitrust authorities. Among the priorities for calculations performed in the paper is its simplicity that does not require a large collection of data and complex mathematical calculations. Data for the calculations were taken from the database MagnusWeb for the year 2012.

\subsection{Theoretical Aspects}

There are absolute and relative indicators for measuring market structures. For example, the number of participants in the market is the absolute indicator. Table 1 shows the existing relative indicators (Morasch, 2002).

Table 1. The overview of relative indicators for measuring market structures

\begin{tabular}{cc}
\hline Abbreviation & Measurement \\
\hline $\mathrm{S}_{\mathrm{i}}$ & Market Share \\
$\mathrm{LI}$ & The Lerner Index \\
$\mathrm{CR}_{\mathrm{n}}$ & The Concentration Ratio \\
$\mathrm{HHI}$ & The Herfindahl-Hirschman Index \\
$\mathrm{CV}$ & The Coefficient of Variation \\
\hline
\end{tabular}

Source: Morasch, 2002

\subsubsection{Market Share $\left(\mathrm{S}_{\mathrm{i}}\right)$}

Market share belongs to the simplest measures of market power and market concentration. Market share is calculated as the ratio of profits, turnover or any other relevant indicator of the firm over total market profits, total market turnover or any other total market relevant indicator. The result is measured in percents:

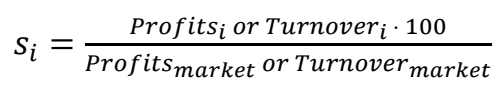

The indicator is often calculated for revenues as:

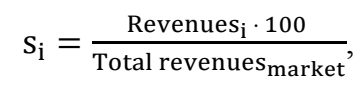

where $\mathrm{S}_{\mathrm{i}}$ is the market share of the $\mathrm{i}$-th firm.

Another method of measuring market share is the ratio of firm's sales volume over total sales volume in the market, expressed in physical units. This method can distort the data and therefore, can not be applicable as an indicator for measuring market competition. Increasing in a market share is often among one of the main goals of a firm. Determining the total size of the relevant market share and the firm's ratio on the total share is a significant indicator for the evalution of a firm's operation, its shares and an indicator for potential investors. Between the advantages of this indicator is its independence from political factors, fiscal policies, tax policies and from other macroeconomic indicators of a country. High concentrated markets are supposed to have one or several dominant firms with market shares which are close to $100 \%$.

\subsubsection{The Lerner Index (LI)}

The Lerner index expresses the degree of profitability of a firm, not its market concentration. The index also serves to assess the market power of a firm. The Lerner index is calculated as the ratio of the difference between the product's price and the marginal cost to the price of this product. The second method of calculation is the inverse ratio of a firm's demand elasticity on the market:

$$
\mathrm{LI}=\frac{(\mathrm{P}-\mathrm{MC})}{\mathrm{P}}=\frac{1}{\left|\mathrm{E}_{\mathrm{d}}\right|}
$$

The Lerner index is calculated for the interval from zero to one. The higher is the value of the index, the greater is a firm's market power. If the index is one, it indicates a monopoly in a market. If the index tends to zero, it indicates the existence of a perfect competition in a market (Holman, 2007). 
The invention of the price/cost margin (P-MC)/P as an index of market power is usually credited to Lerner. Some authors state, that it was not Lerner who invented the price/cost margin index and that the generalized version was fully derived even before the Second World War (WWII). They state that priority should be given to Luigi Amoroso, the leading Italian mathematical economist in the interwar decades (Amoroso, 1954). In the latter case some authors also credit Heinrich von Stackelberg and George Stigler for the invention of the price/cost margin index (Giocoli, 2012). Feinberg, Dickson and others authors recommend to use the Lerner index combining seller concentration with buyer concentration, which is usually correlated with the Lerner index and "seems useful as a structural proxy for the degree of monopoly power in force" (Feinberg, 1980) (Dickson, 1979). Practical researches on the Lerner index were conducted by Domowitz, Hubbard and Peterson in 1988, and later in 1993, in which the authors analyzed and calculated the average value of the Lerner index for manufacturing companies in the United States. This value acheived 0.37 which indicated a medium concetrated competition between a monopoly and a perfect competition. The use of the Lerner index is problematic in practice and therefore is used for theoretical aspects (Domowitz, Hubbard \& Peterson, 1986).

\subsubsection{The Concentration Ratio $\left(\mathrm{CR}_{\mathrm{n}}\right)$}

The concentration ratio measures the percentage of the market's total share supplied by its " $\mathrm{n}$ " largest firms (Mankiw, 2012). Shares can be measured by revenues, profits, operating profits, turnover or any other relevant indicator. The value of " $n$ " is often four, but may be five, six, eight, twelve or any other small number. The concentration ratio can be expressed as:

$$
\mathrm{CR}_{\mathrm{n}}=\mathrm{S}_{1}+\mathrm{S}_{2}+\ldots \mathrm{S}_{\mathrm{n}}=\sum_{\mathrm{i}=1}^{\mathrm{n}} \mathrm{S}_{\mathrm{i}},
$$

where $S_{i}$ is the market share of the $\mathrm{i}$-th firm and $C R_{n}$ is the concentration ratio of $\mathrm{n}$ largest firms. The higher is the concentration ratio, the higher is the concentration on the market. For example, if $\mathrm{CR}_{4}=80 \%$, it means that the four largest firms cover $80 \%$ of the total market share.

The concentration ratio is usually calculated for oligopolistic market structures. One of the advantages of the concentration ratio is its simplicity in application and description. However, the concentration ratio does not provide information about the size of corporations within the peer group (Morasch, 2002). The mathematical problem of the indicator is the use of a simple sum of market shares. For example, if $\mathrm{CR}_{4}$ is $80 \%$, it may mean that the strongest firm occupies $71 \%$ of the market and the other three firms have only $3 \%$ of the market. The similar value of the concentration ratio $\left(\mathrm{CR}_{4}=80 \%\right)$ can be achieved when each of four strongest firms in a market achieves exactly $20 \%$ from total market shares. Therefore antitrust authorities use concentration ratios of four largest firms on the market along with the Herfindahl-Hirschman index for assessing the degree of market concentration. The Czech Office for Protection of Competition also uses concentration ratios along with the Herfindahl-Hirschman index. For a long-term practice of antitrust authorities, these indicators are supposed to be the most appropreate for measuring market structures.

The following table summarizes the significant intervals of values of concentration ratios, which are used by antitrust authorities and which are also used in the practical part of the analysis. For example, if the $\mathrm{CR}_{4}$ is close to 0 and less than $40 \%$ (indicating that the four firms own less than $40 \%$ of the market), then the market is considered to be rather competitive. On the other hand, if the $\mathrm{CR}_{4}$ is close to $100 \%$, the market structure is determined as a highly concentrated monopoly.

Table 2. The overview of concentration ratios' intervals

\begin{tabular}{cc}
\hline The concentration ratio of four largest firms & Type of market structures \\
\hline $\mathrm{CR}_{4}<40 \%$ & Perfect competition; monopolistic competition \\
$60 \%>\mathrm{CR}_{4}>40 \%$ & Loose oligopoly \\
$\mathrm{CR}_{4}>60 \%$ & Tight oligopoly \\
$\mathrm{CR}_{1}>90 \%\left(\mathrm{CR}_{4} \rightarrow 100 \%\right)$ & Monopoly \\
The concentration ratio of four largest firms & Type of market structures \\
\hline
\end{tabular}

Source: Merger Assessment Guidelines, 2010

The European Commission and national competition authorities have different rules for the identification of a type of market competition and of a firm's dominant position on the market. The following Table 3 shows one of the main indicators in assessing the conduct of dominant undertakings. 
Table 3. Concentration ratio's criteria in certain countries

\begin{tabular}{cc}
\hline Country & The Concentration ratio $\left(\mathrm{CR}_{1}\right)$ \\
\hline The United Kingdom & $>25 \%$ \\
The Czech Republic & $>40 \%$ \\
European Union & $\geq 25 \%$ \\
Country & The Concentration ratio $\left(\mathrm{CR}_{1}\right)$ \\
The United Kingdom & $>25 \%$ \\
\hline
\end{tabular}

Source: Merger Assessment Guidelines, 2010 \& Office for the Protection of Competition, 2014

The concentration ratio is given by market shares of " $n$ " strongest firms. Perfect competitions and monopolistic competitions are suggested to be "safe" for a market. It means that there are no fines and penalties for these types of a market and therefore regulation is futile. Loose oligopolies may also be legal and "safe" for a market; however, a further investigation should be started for this particular market structure. Tight oligopolies and monopolies are risky and inefficient; therefore, a further investigation is usually started. Antitrust authorities investigate the possibility of the existence of illegal agreements and the possibility of setting prohibited pricing policies for these types of a market.

\subsubsection{The Herfindahl-Hirschman Index (HHI)}

Antitrust authorities apply the Herfindahl-Hirschman Index (HHI) as a key indicator for measuring market structures. Index was invented and firstly used by Orris C. Herfindahl in his dissertation "Concentration in the U.S. steel industry" in 1950; and independently Albert O. Hirschman implemented the same method of measuring market structures in his book "National power and the structure of foreign trade" in 1945. Therefore the indicator was named as the Herfindahl-Hirschman index (Herfindahl, 1950) (Hirschman, 1945).

The Herfindahl-Hirschman index (HHI) is an indicator of market concentration, which is calculated by squaring the percentage market share of each firm in the market and summing these numbers:

$$
\mathrm{HHI}=\sum_{\mathrm{i}=1}^{\mathrm{n}} \mathrm{S}_{\mathrm{i}}{ }^{2} \text {, }
$$

where "Si" is the market share of the i-th firm and " $n$ " is the number of firms in a market (Holman 2007). For example, in a market with two equal-sized firms with the market share of $50 \%$, the Herfindahl-Hirschman index equals: $50^{2}+50^{2}=5000$. The HHI index for the market consisting of four firms with shares of $30 \%, 30 \%, 20 \%$ and $20 \%$ would be: $900+900+400+400=2600$.

HHI is calculated in the interval from 0 to 10000 . The higher is the index value, the higher is the degree of a market concentration and thus the market is more inefficient and is more needed in regulation. The index achieves the value of 10000 if the market is a pure monopoly (100*100). Otherwise, the lower is the index the more competitive is the market (if an industry has 1000 companies each with $0.1 \%$ market share, then the index would be only 10). Market structures are distinguished according to the HHI index values for the following types:

Table 4. The HHI index value

\begin{tabular}{cc}
\hline The HHI index & Market concentration \\
\hline$<0.01$ (or 100$)$ & Highly competitive market \\
$<0.15$ (or 1500$)$ & Unconcentrated market \\
$0.15<$ the HHI index $<0.25$ (or 1500 to 2500$)$ & Moderate concentration \\
$>0.25$ (or 2500$)$ & High concentration \\
\hline
\end{tabular}

Source: Merger Assessment Guidelines, 2010

Antitrust authorities strictly supervise the markets, which have HHI index values greater than 1500 . Mergers and acquisitions, which would increase the HHI index by more than 100 are also strictly controlled by antitrust authorities in the context of compliance with the international competition law.

The Herfindahl-Hirschman index better reflects a concentration in a market than usual indicators of concentration ratios from a mathematical point of view. Economists believe that traditional concentration ratios do not reflect the size of a particular firm within the peer group and therefore do not measure the market power of the largest firms in the market as effectively as the HHI index. The Herfindahl-Hirschman index assigns square weight of companies with a high market share. This difference can be illustrated in the followng example: there are two markets with ten firms in each. Market shares for the first market are: 20, 15, 15, 15, 10, 5, 5, 5, 5, 
5. Market shares for the second market are: 45, 7, 7, 6, 6, 6, 6, 6, 6, 5. Therefore, the concentration ratios of both markets are similar: $\mathrm{CR}_{4}=65 \%$. It means that it is a tight oligopoly and antitrust authorities should initiate further investigation of the market. But if we calculate the HHI index of both markets, we shall get:

$$
\begin{gathered}
\text { HHI market } 1=20^{2}+15^{2+} 15^{2+} 15^{2}+10^{2}+5^{2}+5^{2}+5^{2}+5^{2}+5^{2}=1300 \\
\text { HHI market } 2=45^{2}+7^{2+} 7^{2+} 6^{2}+6^{2}+6^{2}+6^{2}+6^{2}+6^{2}+5^{2}=2364
\end{gathered}
$$

Concentration ratios for both markets are similar, but the HHI index says that the concentration for the second market is larger than the concetration for the the first market. In the second market, the largest firm within the market achieves a dominant position that may cause unfair practices within the market. In the first market, four largest firms divide the largest part of the market, where the largest firm ownes $20 \%$ form the total market share. The next table shows the results of the example.

Table 5. Example of measuring market structures

\begin{tabular}{cccc}
\hline $1^{\text {st }}$ market & Concentration ratios for the $1^{\text {st }}$ market & $2^{\text {nd }}$ market & Concentration ratios for the $2^{\text {nd }}$ market \\
\hline 10 firms & Oligopolistic comptition & 10 firms & Oligopolistic comptition \\
CR4 $=65 \%$. & Tight oligopoly & CR4 $=65 \%$. & Tight oligopoly \\
HHI $=1300$ & Unconcentrated market & HHI $=2364$ & Moderate concentration \\
\hline
\end{tabular}

Source: own calculations

The normalized Herfindahl index ranges from 0 to 1 and it is calculated as:

$$
\mathrm{H}^{*}=\frac{\mathrm{HHI}-\frac{1}{\mathrm{n}}}{1-\frac{1}{\mathrm{n}}}
$$

where " $n$ " is the number of firms in the market, " $H^{*}$ " is the normalized Herfindahl index and "HHI" is the Herfindahl-Hirschman index.

The HHI index is sensitive to changes in the sizes of the largest firms in the market. For example, it increases if the largest firm gains $10 \%$ share at the expense of the second largest firm. Thus, if the relative size of the largest firms is an important determinant for the investigation, the Herfindahl index tends to be more useful than a standard n-firms concentrated ratio.

However, the index is directly dependent on a proper definition of a particular market. The key problems in defining the market is choosing a geographic scope or indicating the market with differentiated products. For example, industry of financial services may contain 6 largest firms with $15 \%$ market share. That situation may seem to be a non-monopolistic. However, one of those firms may handle $90 \%$ of the checking accounts (and overcharge for them because of its monopoly), and the others may primarily do commercial banking and investments. In this scenario, people would be suffering due to the market dominance by one firm. Another typical problem is connected with a geographic scope. For example, each firm may have $20 \%$ market share, but may occupy five areas of the country in which they would be monopoly providers. This factor is important for local businesses - for example, telemarketing services are rather global in scope, while shoe repair services are local.

\subsubsection{The Coefficient of Variation (CV)}

The coefficient of variation is another relative indicator for the measurement of market structures. It measures the standard deviation of Herfindahl index. The CV is used in case of large quantities of firms in the market. Generally, the coefficient of variation is a normalized measure of dispersion of a probability distribution or frequency distribution. The coefficient of variation is defined as the ratio of the standard deviation $\sigma$ to the mean $\mu$ :

$$
\mathrm{c}_{\mathrm{v}}=\frac{\sigma}{\mu}
$$

The absolute value of the CV can be calculated as a relative standard deviation (RSD), which expresses the variation as a percentage of the mean:

$$
\mathrm{c}_{\mathrm{v}} \%=\left(\frac{\sigma}{\mu}\right)
$$

The simplest statistic is the mean or average. For example, given the amount of profit for 5 years of a firm: 90 , $80,30,80,50$, the mean or $\mathrm{x}$ bar or $\bar{x}$ is $330 / 5$ or 66 . The mean value characterizes the "central tendency" or "location" of the data. The values observed will show a dispersion or distribution about the mean, and this 
distribution needs to be characterized to set a range of acceptable control values. The predicable dispersion or standard deviation $(\sigma)$ can be calculated as follows:

$$
\sigma=\sqrt{\frac{\sum\left(\mathrm{x}_{\mathrm{i}}-\overline{\mathrm{x}}\right)^{2}}{(\mathrm{n}-1)}}
$$

The next table shows the example of calculating the coefficient of variation for a market:

Table 6. Example of calculating the coefficient of variation

\begin{tabular}{|c|c|c|}
\hline$x_{i}$ & $x_{i}-\bar{x}$ & $\left(\mathrm{x}_{\mathrm{i}}-\overline{\mathrm{x}}\right)^{2}$ \\
\hline 90 & 24 & 576 \\
\hline 80 & 14 & 196 \\
\hline 30 & -36 & 1296 \\
\hline 80 & 14 & 196 \\
\hline 50 & -16 & 256 \\
\hline \multicolumn{3}{|c|}{ Total } \\
\hline$\sum \mathrm{x}_{\mathrm{i}}=330$ & $\sum\left(\mathrm{x}_{\mathrm{i}}-\overline{\mathrm{x}}\right)=0$ & $\sum\left(\mathrm{x}_{\mathrm{i}}-\overline{\mathrm{x}}\right)^{2}=2520$ \\
\hline
\end{tabular}

Source: own calculations

Then,

$$
\begin{gathered}
\sigma=\sqrt{\frac{\sum\left(\mathrm{x}_{\mathrm{i}}-\overline{\mathrm{x}}\right)^{2}}{(\mathrm{n}-1)}}=\sqrt{\frac{2520}{4}}=25,099 \\
\mathrm{c}_{\mathrm{v}}=\frac{\sigma}{\mu}=\frac{25,0998}{66}=0,3803, \text { or } \mathrm{c}_{\mathrm{v}} \%=38,03 \%
\end{gathered}
$$

The coefficient of variation provides general results about the performance of a method. For example, coefficients of variation of $5 \%$ or less generally give results as a good method performance, whereas coefficients of variation of $10 \%$ and higher are estimated as bad results. However, before judging a coefficient of variation, the mean value should be carefully observed. Therefore, at low concentrations, the CV may be high, and otherwise, at high concentrations the CV may be low. However, it is very useful statistic indicator for comparing the degree of variation from one data series to another, even if the means are drastically different from each other, as far as it is a dimensionless number. That is why this coefficient is used for comparison data sets with widely different means instead of using the standard deviation. This is often the case if the values do not originate from a ratio scale. Moreover, unlike the standard deviation, it cannot be used directly to construct confidence intervals for the mean (Morasch, 2002)

\subsection{Empirical Aspects}

The analytical part of the paper shows the example of using indicators of market structures for the analyzed industry. For measuring market concentration were used primarily market shares for the selected stages of the dairy market, concentration ratios of four, six and eight largest firms $\left(\mathrm{CR}_{\mathrm{n}}\right)$ and the Herfindahl-Hirschman Index (HHI).

In the first stage of the dairy market stays production of milk or "raising of dairy cattle", which is classified according to the Czech classification of economic activities "CZ-NACE" to the section "A" number "01.41". The result of the analysis is shown in the following table:

Table 7. Market shares for the first stage of the dairy market "raising of dairy cattle" (CZ-NACE, section A, number 01.41), 2012

\begin{tabular}{lcccc}
\hline & Name of a firm & ID number & Revenues (CZK) & Market share (\%) \\
\hline 1 & ALIMEX NEZVĚSTICE a.s. & 25196049 & 188818000 & 20.30 \\
2 & NETIS, a.s. & 25838938 & 147868000 & 15.90 \\
3 & Valašské ZOD, družstvo & 47151641 & 72191000 & 7.76 \\
4 & Zemědělské družstvo MÍR se sídlem v Ratiboři & 151246 & 72071000 & 7.75 \\
5 & Zemědělská a.s. Horní Bradlo & 25995421 & 66391000 & 7.14 \\
6 & Ústav pro strukturální politiku v zemědělství,a.s. & 25319515 & 61211000 & 6.58 \\
7 & ZEFA Volary s.r.o. & 26074303 & 44446000 & 4.78 \\
8 & ZOD Poruba a.s. & 47673516 & 42649000 & 4.58 \\
\hline
\end{tabular}

Source: own calculations 
Table 7 shows the concentration ratio of eight largest firms in the industry is $74.78 \%\left(\mathrm{CR}_{8}\right)$ from total revenues of the peergroup. The concentration ratio of six largest firms is $65.42 \%\left(\mathrm{CR}_{6}\right)$, and the concentration ratio of four largest firms is $51.70 \%\left(\mathrm{CR}_{4}\right)$. The largest company in the industry is "ALIMEX Nezvěstice a.s." the second largest company is "NETIS, a.s.", the third largest firm is "Valašské ZOD, družstvo" and the fourth is "Zemědělské družstvo MíR se sídlem v Ratiboři". The smallest market share in the "big eight" belongs to the firm "ZOD Poruba a.s." with its market share of $4.58 \%$.

There were registered 33 firms within the industry for the year 2012; eight largest firms were presented in Table 7. Total revenues of the industry were $930214000 \mathrm{CZK}$ for the analysed year. The procedure of calculating the HHI index is as follows:

1. Identification of firms within the industry and its revenues;

2. Calculation of total industry revenues (930 $214000 \mathrm{CZK}$ ) according to the Equation 4: " $\Sigma \mathrm{Si}$ ";

3. Calculation of each firm's market share as it is presented in the Equation 2. For example, for "ALIMEX Nezvěstice a.s." the market share is calculated as: $(188818000 * 100) / 930214000=20.3 \%$.

4. Calculation of the squared market shares of each firm. For example, for "ALIMEX Nezvěstice a.s." the squared market share is: $20.3^{2}=412$;

5. Calculation of the sum of the squared market shares as it is presented in the Equation 5: " $\Sigma \mathrm{Si}^{2}$ ",

Thus we have acheived the final value of the HHI index, which is 960.50 . This value represents unconcentrated market. The concentration ratio of four largest firms reaches $51.70 \%$, and it highlights the existence of a loose oligopoly in the industry. According to the calculated indicators, the antitrust authority should not interfere in the industry "raising of dairy cattle" (CZ-NACE 01.41).

The second stage in the dairy market belongs to the industry "wholesale of dairy products, eggs and edible oils and fats", which is classified by the Czech classification of economic activities "CZ-NACE" to the section "G" number " 46.33 ". The result of the analysis for the year 2012 is given in the following table:

Table 8. Market shares for the second stage of the dairy market "wholesale of dairy products, eggs and edible oils and fats" (CZ-NACE, section G, number 46.33), 2012

\begin{tabular}{lcccc}
\hline & Name of a firm & ID number & Revenues (CZK) & Market share (\%) \\
\hline 1 & UNILEVER ČR, spol. s r.o. & 18627781 & 4252738000 & 11.79 \\
2 & ALIMPEX FOOD a.s. & 47115807 & 4205259000 & 11.66 \\
3 & Lactalis CZ, s.r.o. & 27132471 & 3442151000 & 9.54 \\
4 & Mlékařské a hospodářské družstvo JIH & 60647876 & 3231904000 & 8.96 \\
5 & Mlékařské hospodářské družstvo Střední Čechy & 61462501 & 1785321000 & 4.95 \\
6 & MILKPOL, SPOL. S R.O. & 62917897 & 1697308000 & 4.71 \\
7 & Morava, mlékařské odbytové družstvo & 60742780 & 1569172000 & 4.35 \\
8 & VIAMILK CZ družstvo & 64259439 & 1323609000 & 3.67 \\
\hline \multicolumn{2}{r}{ Total } & 21507462000 & 59.64 \\
\hline
\end{tabular}

Source: own calculations

As we can see from the Table 8 , the concentration ratio of eight largest firms in the industry (the $\mathrm{CR}_{8}$ ) is $59.64 \%$ from total revenues of the peergroup. The concentration ratio of six largest firms is $51.61 \%$, and the concentration ratio of four largest firms is $41.96 \%$. The largest firm in the industry is "UNILEVER ČR, spol. s.r.o.", the second largest firm is "ALIMPEX FOOD a.s.", the third largest firm is "Lactalis CZ, s.r.o.", and the fourth largest firm is "Mlékařské a hospodářské družstvo JIH". The smallest market share in the "big eight" belongs to the firm "VIAMILK CZ družstvo" with its market share of $3.67 \%$. The firm "UNILEVER ČR, spol. s.r.o." was excluded from the analysis because a larger part of its revenues belongs to the production and sale of edible oils and fats. Wholesale of dairy products has no effect on the revenues of the firm.

There were 69 firms, which were registered in the industry in 2012. Total revenues of all firms within the industry including the firm "UNILEVER ČR, spol. s.r.o." was 36064547000 CZK in the year 2012. The procedure of calculating of concentration ratios and the $\mathrm{HHI}$ index for the second stage is similar as it was used in the first stage.

The HHI index for the industry "wholesale of dairy products, eggs and edible oils and fats" is 595 . This value represents unconcentrated market. The concentration ratio of four largest firms reaches $41.96 \%$, and it 
highlights the existence of a loose oligopoly in the industry. The concentration ratio of four largest firms without the firm "UNILEVER ČR, spol. s.r.o." is 35, $2 \%$, which is less than $40 \%$. This value represents the existence of perfect competition or monopolistic competition within the industry. According to the calculated indicators, the antitrust authority should not interfere in the industry "wholesale of dairy products, eggs and edible oils and fats" (CZ-NACE 46.33) because its values indicate low concentration and high competition within the market.

The third stage in the dairy markets is the "operation of dairies and cheese making", which is classified by the Czech classification of economic activities "CZ-NACE" to the section "C" number "10.51". The result of the analysis for the year 2012 is given in the following table:

Table 9. Market shares for the third stage of the dairy market "operation of dairies and cheese making" (CZ-NACE, section C, number 10.51), 2012

\begin{tabular}{lcccc}
\hline & Name of a firm & ID number & Revenues (CZK) & Market share (\%) \\
\hline 1 & MADETA a. s. & 63275635 & 5064080000 & 15.44 \\
2 & Mlékárna Pragolaktos, a.s. & 27133079 & 4396583000 & 13.40 \\
3 & OLMA, a.s. & 47675730 & 3019566000 & 9.20 \\
4 & Danone a.s. & 45272972 & 2612690000 & 7.96 \\
5 & Mlékárna Hlinsko, a.s. & 48169188 & 2190758000 & 6.68 \\
6 & ORRERO a.s. & 63319551 & 1761084000 & 5.37 \\
7 & BEL Sýry Česko a.s. & 60714603 & 1269475000 & 3.87 \\
8 & Moravia Lacto a. s. & 49969897 & 1259254000 & 3.84 \\
\hline
\end{tabular}

Source: own calculations

As we can see from the Table 9, the concentration ratio of eight largest firms in the industry $\left(\mathrm{CR}_{8}\right)$ is $65.76 \%$ from total revenues of the peergroup. The concentration ratio of six largest firms is $58.05 \%$, and the concentration ratio of four largest firms is $46 \%$. The largest firm in the industry is "MADETA a.s.", the second largest firm is "Mlékárna Pragolaktos, a.s.", the third largest firm is "OLMA, a.s.", and the fourth largest firm is "Danone a.s.". The smallest market share in the "big eight" belongs to the firm "Moravia Lacto a.s." with its market share of $3.84 \%$ from total revenues of the industry.

There were 53 firms, which were registered in the industry in 2012. Total revenues of all firms within the industry was $32807129000 \mathrm{CZK}$ in the year 2012. The procedure of calculating of concentration ratios and the HHI index for the third stage is similar as it was used in the first stage. The HHI index for the industry "operation of dairies and cheese making" is 741 units. This value represents unconcentrated market. The concentration ratio of four largest firms reaches $46 \%$, and it highlights the existence of a loose oligopoly in the industry. According to the calculated indicators, the antitrust authority should not interfere in the industry "operation of dairies and cheese making" (CZ-NACE 10.51) because its values indicate low concentration and high competition within the market.

The fourth stage in the dairy markets is the "retail sale in non-specialised stores with food, beverages or tobacco predominating", which is classified by the Czech classification of economic activities "CZ-NACE" to the section "G" number "47.11". The result of the analysis for the year 2012 is given in the following table:

Table 10. Market shares for the fourth stage of the dairy market "retail sale in non-specialised stores with food, beverages or tobacco predominating" (CZ-NACE, section G, number 47.11), 2012

\begin{tabular}{lcccc}
\hline & Name of a firm & ID number & Revenues (CZK) & Market share (\%) \\
\hline 1 & Kaufland Česká republika v.o.s. & 25110161 & 48161404000 & 16.09 \\
2 & Tesco Stores ČR a.s. & 45308314 & 44192000000 & 14.77 \\
3 & AHOLD Czech Republic, a.s. & 44012373 & 40704556000 & 13.60 \\
4 & Penny Market s.r.o. & 64945880 & 29861067000 & 9.98 \\
5 & Lidl Česká republika v.o.s. & 26178541 & 24724284000 & 8.26 \\
6 & Globus ČR, k.s. & 63473291 & 24227311000 & 8.09 \\
7 & BILLA, spol. s r.o. & 685976 & 20546437000 & 6.86 \\
8 & SPAR Česká obchodní společnost s.r.o. & 27207048 & 13188730000 & 4.41 \\
\hline \multicolumn{2}{r}{ Total } \\
\hline
\end{tabular}

Source: own calculations 
As we can see from the Table 10 , the concentration ratio of eight largest firms in the industry $\left(\mathrm{CR}_{8}\right)$ is $82 \%$ from total revenues of the peergroup. The concentration ratio of six largest firms is $71 \%$, and the concentration ratio of four largest firms is $54 \%$. The largest firm in the industry is "Kaufland Česká republika v.o.s.", the second largest firm is "Tesco Stores ČR a.s.", the third largest firm is "AHOLD Czech Republic, a.s.", and the fourth largest firm is "Penny Market s.r.o.". The smallest market share in the "big eight" belongs to the firm "SPAR Česká obchodní společnost s.r.o." with its market share of $4.41 \%$ from total revenues of the market.

There were 437 firms, which were registered in the industry in 2012. Total revenues of all firms within the industry was $299298923000 \mathrm{CZK}$ in the year 2012. The procedure of calculating of concentration ratios and the HHI index for the fourth stage is similar as it was used in the first stage. The HHI index for the industry "retail sale in non-specialised stores with food, beverages or tobacco predominating" is 976. This value represents unconcentrated market. The concentration ratio of four largest firms reaches $54 \%$, and it highlights the existence of a loose oligopoly in the industry. According to the calculated indicators, the antitrust authority should not interfere in the industry "retail sale in non-specialised stores with food, beverages or tobacco predominating" (CZ-NACE 47.11) because its values indicate low concentration and high competition within the market. Similar results were presented in the article of Severová, L., Kopecká, L., Svoboda, R. and Brčák, J. "Oligopoly competition in the market with food products" where authors evaluated chain stores in the Czech Republic. They have evaluated ten most significant firms within the industry and none of the analyzed firms met the criterion of a dominant place in the market with market shares more than $40 \%$. Their analysis was prooved by the shares of companies in the Czech food products market, where none of analyzed firms met the criterion of dominance in the market (Severová et al., 2011).

\section{Results}

The results of the analysis are presented in the following table, which illustrates calculated indicators for measuring dairy market structures.

Table 11. Market shares calculated for all stages of the dairy market, 2012

\begin{tabular}{ccccc}
\hline $\begin{array}{c}\text { Industry } \\
(\mathrm{CZ}-\mathrm{NACE})\end{array}$ & $\begin{array}{c}\text { Number of firms } \\
\text { in the industry }\end{array}$ & $\begin{array}{c}\text { The HHI } \\
\text { index }\end{array}$ & $\mathrm{CR}_{4}(\%)$ & Type of a market structure \\
\hline 01.41 & 33 & 960,50 & 51.70 & Unconcentrated market; Loose oligopoly \\
46.33 & 69 & 595 & 41.96 & Unconcentrated market; Loose oligopoly \\
10.51 & 53 & 741 & 46.00 & Unconcentrated market; Loose oligopoly \\
47.11 & 437 & 976 & 54.00 & Unconcentrated market; Loose oligopoly \\
\hline
\end{tabular}

Source: own calculations

Table 11 shows that the HHI index is smaller than 1500 for all stages of the dairy markets. Therefore, the values of the index indicate the existence of unconcentrated markets within the analysed industries. Concentration ratios calculated for the stages in the dairy markets are bigger than $40 \%$ and these values indicate the existence of a loose oligopoly in the industries. The absolute number of firms in the industry is the largest in the case of "retail sale in non-specialised stores with food, beverages or tobacco predominating" (CZ-NACE 47.11) where there were 437 active firms in 2012. Generally, all stages have less than 70 firms. This means that evaluation of the market is located on the border between the oligopolistic and the perfect competition. The answer for the question whether a firm can control the market or not depends on the further analysis. However, indicators show a low concentration and a high competition within the market. It means that antitrust authorities should not interfere in industries and the best policy for the analyzed market is the laissez faire economics, which implies policy of minimum governmental interference in the economic affairs of individuals and society.

\section{Discussion}

There are absolute and relative indicators for measuring market structures. Absolute indicators are the simplest ones. If the absolute number of firms is extremely small (1-6 firms), we can assume the existence of imperfect competition in the market; if the absolute number of firms is high, then it is important to examine market shares before determing a market structure. It may happen that one of firms (or group of firms) will have a larger market share than any other firm, and thus may lead to the existence of oligopolies or monopolies in the market. Therefore, in addition to the absolute number of firms in the industry, there are relative indicators, such as: market shares; the Lerner index; the concentration ratio; the Hefindah-Hirschman index; the coefficient of variation. 
The relative indicators were mentioned in the theoritical part of the paper. The most common indicators used by antitrust authorities are market shares, the concentration ratio and the Herfindahl-Hirschman index. The use of these indicators was presented in the practical part of the analysis for the Czech dairy market, which contains four stages: milk production; processing and pasteurization of milk; wholesale and retail of milk.

Measurement of market power and market concentration is essential in the issue of antitrust laws, and in further market analysis. The indicators determine a type of competition in a market, its calculation do not require a lot of data and difficult calculations. Not only indicators of measuring market structures, but also a careful market schemes, including an analysis of the biggest firms, customers, existence of substitutes and market effects of international trade are essential for the analysis of market structures. That is why further methods of strategical and financial analysis are also used before determing a type of a market structure.

\section{Acknowledgments}

This study is supported by the Internal Grant Agency of Faculty of Economics and Management, Czech University of Life Sciences Prague (Projects No. 20151024 - Models of spatial differentiation and their use in the markets for food production).

\section{References}

Amoroso, L. (1954). The static supply curve. International Economic Papers (English translation of Amoroso 1930), 4, 39-65.

Department of Justice and the Federal Trade Commission. (2010). Merger Assessment Guidelines (Horizontal Merger Guidelines U.S.). Retrieved from http://www.justice.gov

Dickson, V. A. (1979). The Lerner index and measures of concentration. Economics Letters, 3, 275-279.

Domowitz, I., Hubbard, R. G., \& Petersen, B. C. (1986). The Intertemporal Stability of the Concentration-Margins Relationship. The Journal of Industrial Economics, 35, 13-34.

Feinberg, R. M. (1980). The Lerner Index, Concentration, and the Measurement of Market Power. Southern Economic Journal, 46, 1180.

Giocoli, N. (2012). Who Invented the Lerner Index? Luigi Amoroso, the Dominant Firm Model, and the Measurement of Market Power. Review of Industrial Organization, 41, 181-191.

Herfindahl, O. C. (1950). Concentration in the U.S. steel industry. Unpublished doctoral dissertation. New York, NY: Columbia University.

Hirschman, A. O. (1945). National power and the structure of foreign trade. Berkeley. California: CA University of California Press.

Holman, R. (2007). Mikroekonomie - středně pokročilý kurs (2nd ed.). Praha: C. H. Beck.

Mankiw, N. G. (2012). Principles of Microeconomics (6th ed.). Camridge: Harvard University.

Morasch, K. (2002). Wettbewerbspolitik und Regulierung. München: Oldenbourg Verlag.

Office for the Protection of Competition. (2014). Office for the Protection of Competition. Retrieved from http://www.uohs.cz

Samuelson, P. A., \& Nordhaus W. D. (2013). Economics (19th ed.). Praha: NS Svoboda.

Severová, L., Kopecká, L., Svoboda, R., \& Brč́k, J. (2011). Oligopoly competition in the market with food products. Agricultural Economics, 12, 580-588.

Úplné Znění. (2014). Zákon č. 143/2001 Sb., o ochraně hospodárské soutěže (Act no. 143/2001 Coll., On Protection of Competition). Retrieved from http://www.ins.sagit.cz

U.S. Census Bureau. (2009). American Community Survey. Retrieved from http://www.census.gov/acs/www/ data_documentation/2009_release/

\section{Copyrights}

Copyright for this article is retained by the authors, with first publication rights granted to the journal.

This is an open-access article distributed under the terms and conditions of the Creative Commons Attribution license (http://creativecommons.org/licenses/by/3.0/). 